April 2011

\title{
Editor's Introduction: MARO: Mass Atrocity Response Operations; A Military Planning Handbook: Selling the Mission and/or Protecting Human Rights?
}

Herb Hirsch

\section{Recommended Citation}

Hirsch, Herb (2011) "Editor's Introduction: MARO: Mass Atrocity Response Operations; A Military Planning Handbook: Selling the Mission and/or Protecting Human Rights?," Genocide Studies and Prevention: An International Journal: Vol. 6: Iss. 1: Article 2.

Available at: https://digitalcommons.usf.edu/gsp/vol6/iss1/2

This Editorial is brought to you for free and open access by the Open Access Journals at Digital Commons @ University of South Florida. It has been accepted for inclusion in Genocide Studies and Prevention: An International Journal by an authorized editor of Digital Commons @ University of South Florida. For more information, please contact digitalcommons@usf.edu. 


\section{Editor's Introduction}

\section{MARO: Mass Atrocity Response Operations; A Military Planning Handbook: Selling the Mission and/or Protecting Human Rights?}

As we enter our sixth year of publication, the editors are very pleased to welcome readers to the sixth volume of Genocide Studies and Prevention. We have been very fortunate over the past five years to present a wide array of material related to the prevention and understanding of genocide and mass atrocities. This volume continues that tradition as it presents a symposium of invited commentaries on MARO: Mass Atrocity Response Operations; A Military Planning Handbook.

$M A R O$ grew out of the United States military Quadrennial Defense Review which contained a statement noting that the military needed to focus on "preventing human suffering due to mass atrocities or large-scale natural disasters abroad." 1 The Carr Center for Human Rights Policy at the Harvard Kennedy School and the US Army Peacekeeping and Stability Operations Institute collaborated in writing MARO.

$M A R O$ is the second recent attempt by the United States or related organizations to design policies to prevent genocide and protect civilian populations. Like its predecessor, Madeleine Albright and William Cohen's Preventing Genocide: A Blueprint for U.S. Policymakers, ${ }^{2} M A R O$ consists of what I would call semi-official US government documents. I say semi-official because these documents are actually sponsored and published by universities or other organizations. They are not official policy pronouncements in the sense that they are only recommendations and have not been incorporated into the decision-making apparatus of the government or the military. In common with virtually all such exercises, including Blueprint, MARO suffers from an excess of bureaucratic jargon, acronyms, diagrams that look as though they were designed by sixth graders after playing video games, and referents that often bear little or no relationship to reality-the reality, in this case, of genocide and mass atrocities. They also often ignore or rewrite history, or perhaps create their own version of history that suits their policy recommendations. All of these and many more specific critical and analytic views are expressed by the authors of the commentaries in this issue.

The immediate background of $M A R O$ is, most likely, the failure to stop the massive human rights violations in the former Yugoslavia and Rwanda in the 1990s. Embarrassed and determined to justify United Sates policy that allowed those atrocities to occur virtually unimpeded, Albright and Cohen's Blueprint was published and followed by the present MARO. The United States had apparently been in denial about the role it played in allowing those atrocities to occur and had retreated from any idea that it would be engaged in protecting human rights as

Herb Hirsch, Editor's Introduction, Genocide Studies and Prevention 6, 1 (April 2011): 1-6. (C) 2011 Genocide Studies and Prevention. doi:10.3138/gsp.6.1.1 
attention turned to terrorism after September 11, 2001. In March 2007 the US Army War College sponsored a conference titled The National Security Implications of Climate Change, and attention began to shift to the possible importance it held for military operations and how it would affect human rights around the globe. As the wars in Afghanistan and Iraq began to slowly recede from public consciousness, the military saw the importance of a new mission in the new environment. This is described as "selling a mission"3 by Gwynne Dyer in his daring new book, Climate Wars: the Fight for Survival as the World Overheats. As he puts it,

The next mission of the U.S. armed forces is going to be the long struggle to maintain stability as climate change continually undermines it. The "war on terror" has more or less had its day and, besides, climate change is a real, full-spectrum challenge that may require everything, from Special Forces to aircraft carriers. So it's time to jolt the rank and file of the officer corps out of their complacency, re-orient them towards the new threat and get them moving. ${ }^{4}$

Of course, this also guarantees continued funding for the military, for those corporations that depend on military funding, and for the congressional districts that contain such installations. It means that when the missions in Afghanistan and Iraq end, the military will have a new mission. It is the answer to the debate started by Eisenhower's military-industrial complex speech and the answer to the questions which have been raised since the end of the Cold War.

In fact, as the Cold War faded into historical anachronism in the 1990s it became clear that the "mission" was ambiguous and not as clear as it had been. What would replace the Cold War? The "war on drugs" was not only inadequate but it was a war that was defeated by the demand for drugs in the US. Until September 11, 2001, there was no adequate factor to sell the mission, to mobilize the fear of the public, and to unite the country behind the military and the new mission. Climate change and the protection of human rights are perfect. Not only do they serve the purpose but they also form a response to a very real threat-a threat, incidentally, that the liberal, humanitarian left has been supporting before the military arrived to pick up the thread that has been woven over the years since the atrocities in the former Yugoslavia and Rwanda in the 1990s.

This is where $M A R O$ fits and it is hard to criticize the now apparent good intentions behind the new mission. As the authors of MARO argue,

The Mass Atrocity Response Operations (MARO) Project seeks to enable the United States and the international community to stop genocide and mass atrocity as part of a broader integrated strategy by explaining key relevant military concepts and planning considerations. The MARO Project is based on the insight that the failure to act in the face of mass killings of civilians is not simply a function of political will or legal authority; the failure also reflects a lack of thinking about how military forces might respond. States and regional and international organizations must better understand and prepare for the unique operational and moral challenges that military forces would face in a MARO. ${ }^{5}$

Accordingly, the Project states that it

addresses the concrete and practical challenges of using military forces to halt ongoing mass atrocities through a MARO. The Project has developed operational concepts, a tailored planning guide, tabletop exercises, and other tools for military institutions and political actors. While military force will not always be required to halt mass atrocity, the MARO Project helps make credible, effective options more likely and it better prepares intervening forces in the event that they are directed to act. In this respect, the Project can help shift the policy debate from "whether" to "how" to intervene to stop widespread violence against civilians. (5) 
And it all sounds very honorable. The US military is now devoted to humanitarian intervention and to the protection of civilian populations if the MARO project is ever adopted and instituted as an official policy response. Several of our commentators note that this is highly unlikely and they explain their reasoning in detail. For now, I simply wish to note that the report begins with faulty premises. Yes, it is true that the "failure to act in the face of mass killings of civilians is not simply a function of political will or legal authority," but it is an oversimplification to argue, as MARO does, that "the failure also reflects a lack of thinking about how military forces might respond." In fact, the United Sates military was reluctant to act in the cases of the former Yugoslavia and Rwanda. The so-called Powell Doctrine, which was a response to the Vietnam Syndrome coupled with the disaster in Somalia in 1993, argued that any response must include a massive infusion of US force along with an exit strategy. Throughout the course of the atrocities in the former Yugoslavia, the US military and its political allies in the Clinton administration argued against intervention on the basis that the long standing ethnic and religious hostilities responsible for the ongoing slaughters were an intractable force that was not amenable to military solution. Similar arguments were made about any possible intervention in Rwanda. The real lesson here is not that there was no military thinking but that there were political reasons why the United States did not wish to intervene and the forces supporting intervention were not politically influential. Neither Bosnia nor Rwanda had sufficient oil reserves to justify action similar to that taken in the Persian Gulf, and there was little or no equivalent to the movement to publicize the atrocities in Darfur and to pressure the government to take action. Even in 2010 with a strong Save Darfur movement supported by students, movies stars, NGOs, and others, the atrocities continued, and there exist reasons why the United Sates does not support intervention and cannot intervene. In fact, in spite of those newer forces there remains a reluctance to intervene as well as powerful political forces militating against any action. Lack of planning, as MARO claims, is not the primary factor, or even a major factor at that, in this reluctance.

The authors of MARO also argue that "The Project has developed operational concepts, a tailored planning guide, tabletop exercises, and other tools for military institutions and political actors" (5-6). "In this respect," the authors continue, "the Project can help shift the policy debate from 'whether' to 'how' to intervene to stop widespread violence against civilians" (6). The problem is that answering the "whether" to intervene question must come before any discussion of "how" to intervene. Here, once again, political factors play a major role. If, however, it is determined that intervention will take place, it does not seem logical to lay out a one-size-fits-all plan since every case is different. The Pentagon has done this to its detriment repeatedly. After World War II planning for war on the European plains did not lead to the successful prosecution of wars in Korea or Vietnam. In fact, the opposite was the case as US strategy was self-defeating and was further undermined by the lack of understanding of the cultural and political situation of both of those conflicts. Therefore, body counts as the measure of success in Vietnam led to atrocities being committed by US troops as any Vietnamese was counted as an enemy casualty, and the policy of free-fire zones led to the mass killing of civilians. Much more important is an in-depth understanding of each situation so that planning may be pursued to develop a successful strategy to meet each exigency.

As an attempt to respond to these factors, $M A R O$ intends to overcome the reluctance to intervene and to instead advocate that it is in the national interest of a nation such as the United States to protect human rights. MARO notes: 
Some argue that it is unlikely that, despite advocacy and education to the contrary, the United States will ever decide that it is within its national strategic interest to launch an intervention to stop a mass atrocity, and therefore that planning for this eventuality is not a priority. Such a position is not only ahistorical; it represents an abdication of responsibility to prepare for contingencies. (14)

Contingencies must indeed be anticipated, but what is ahistorical is to interpret past US foreign policy as intervening to protect human rights. In fact, the United States has not identified intervention to stop mass atrocities as part of its strategic interest. To be sure, that does not mean planning should not occur, but it does mean that undertaking such intervention would be a new and unusual step for the United States. The $M A R O$ authors note this to some extent:

A Mass Atrocity Response Operation (MARO) describes a contingency operation to halt the widespread and systematic use of violence by state or non-state armed groups against non-combatants. The term MARO is not yet enshrined in military doctrine-but it should be. The United States does not currently recognize mass atrocities as a unique operational challenge, and there is no operational concept or doctrine that might help commanders understand the dynamics and demands of responding to mass atrocities. (17)

To rectify this, MARO argues that while the United States is not fully prepared to intervene effectively in a mass atrocity situation, past military operations provide guidelines and MARO will be familiar because it will include many traditional operations:

This is true almost across the operational spectrum: convoy escort, direct fires, and detainee operations are features of both peacekeeping and war. More broadly, a MARO involves a dynamic mix of offense, defense, and stability operations. Many familiar operational concepts, such as no-fly zones, protected enclaves, or separation of forces, may be elements of a MARO operational plan. (24)

In short, MARO differs from more traditional military operations only in the fact that it intends to stop atrocities and help protect civilian populations. MARO next attempts to incorporate the US experience in Operation Iraqi Freedom as a case study, noting, "Consider the US experience in Operation Iraqi Freedom, in which the context changed from major combat operations to counterinsurgency. Although many of the tasks and concepts remained the same, US forces were inadequately prepared to carry them out" (24). Of course, this is the case and it is no different, as I argued above, from the experience in Vietnam or Afghanistan. What was lacking was not a MARO plan but knowledge of the culture, politics, social structure, the entire underpinnings and history - in fact_of those experiencing US military intervention. Consequently, Iraq is a particularly poor choice; US operations in Iraq were not originally sanctioned as multilateral and the United States is at fault for not being prepared to engage counterinsurgency operations. After years of counterinsurgency experience in places such as Vietnam, not to mention the former Soviet Union's experience in Afghanistan, the US military's lack of preparation for this is, indeed, a sad comment on the military.

Finally, it is important to ask whether an operation plan outlining what should be done is necessary. Does this explain the inability to be flexible and to adapt to new circumstances? If so, the US military will always be at a disadvantage to guerrilla groups which adapt quickly to their changing circumstances. To its credit, MARO incorporates this into its analysis, noting, "Indeed, the asymmetry 
between a rushed genocide and a graduated response has important-and somewhat contradictory-implications for intervention. The asymmetry works against those who want to stop mass atrocities," and a successful model of military intervention must take that into account (29). This is important to note, and yet doing so does not mean that a written plan will adequately prepare a military force to respond in such fashion.

The authors of $M A R O$ are not unaware of the most telling criticisms that may be made of their operational handbook; nor are they ignorant of the history of genocide and human rights atrocities. To their credit, they attempt to anticipate most of the comments to be found in the following analyses. Yet, they faced a massive and perhaps insoluble task in trying to present a military plan that would anticipate the contingencies of inherently unstable and quickly changing circumstances. The authors are aware of this issue and, consequently, argue for the necessity of education as well as the necessity of "developing doctrine, leader orientation, conducting routine planning exercises, and developing common national and coalition concepts, vocabulary, and expectations. Any multinational execution of this type of mission will require a high degree of coordinated political and military effort" (30). Acquiring the necessary training for such a mission is a complicated process and requires some highly specialized forms of training including the acquisition of the language, culture, or context within which operations may need to take place. The level of difficulty that is involved in the process becomes evident when one notes that this type of training - which includes ongoing historical, cultural, and linguistic education of a highly complicated nature for most of the regions of the world-prepares for a mission that intends to anticipate the possibility of atrocities.

As $M A R O$ trudges to its conclusion, it rushes to include a discussion of very complicated factors to be taken into consideration such as the importance of NGOs, the moral dilemmas that might be confronted, the aftermath of such atrocities, and the responsibility to help with the recovery and reconstruction processes. For this reason, although $M A R O$ contains errors of omission and commission, it is a valiant attempt to redefine the mission of the US military to incorporate a consciousness of the necessity of protecting human rights. Whether it is selling a new mission in order to preserve the defense establishment or it is motivated by a genuine desire to protect civilian populations, the least that can be said about it is that MARO opened a discussion and gave rise to a level of consciousness that until now appeared to be beyond the pale of discussion. For many more specific and interesting criticisms and analyses of both the positive and negative implications of the project as well as for practical considerations of the issues related to the implementation of the recommendations that $M A R O$ advances, I encourage you to read the following commentaries very carefully.

Since the commentaries cover a wide range of topics from diverse perspectives it would be difficult to summarize them. I have divided and organized them into two categories: scholarly perspectives from outside of the United States and scholarly perspectives from within the United States-a method that offers some interesting alternative views. The commentaries can also be divided in terms of the theoretical or practical perspective that they adopt.

The editors of Genocide Studies and Prevention hope that these various views will contribute to the ongoing attempt to protect human rights and prevent atrocities.

The second part of this issue consists of an article and a research note. The article by Marko Attila Hoare-a reader at the Faculty of Arts and Social Sciences, Kingston University - is a case study of the international courts and genocide in 
Bosnia-Herzegovina. Hoare notes that two international courts, the United Nations International Criminal Tribunal for the former Yugoslavia (ICTY) and the International Court of Justice (ICJ), established that genocide occurred in Srebrenica in 1995. Additional courts have concurred and yet, as Hoare notes, "there has been minimal international punishment in Bosnia." 6 This article attempts to explain and analyze why "international justice has underachieved regarding the mass murder in Bosnia by examining the structural weaknesses, political pressures, and errors of judgment that have hampered the international court."7

The research note by Antonis Klapsis, adjunct lecturer in the Department of Political Science and International Relations, University of Peloponnese, brings attention to one of the lesser known mass atrocities that has taken place in the twentieth century. Klapsis provides an in-depth analysis of the measures undertaken by the US government to aid the Greek refugees escaping the atrocities in Asia Minor from 1922 to 1923. This analysis is not only important as a description of how humanitarian aid can be offered but, as I noted above, it also fills in another chapter of the history of a lesser known genocide.

In conclusion, as we begin our sixth year of publication, we, the editors of Genocide Studies and Prevention, intend to maintain our ongoing commitment to do everything that we can to help our readers understand the causes of genocide and to continue to help end what is increasingly accepted as one of the most egregious crimes against humanity.

Herb Hirsch

GSP Co-editor

\section{Notes}

1. Department of Defense, Quadrennial Defense Review Report, February 2010, http://www.defense.gov/qdr/images/QDR_as_of_12Feb10_1000.pdf, p. vi.

2. Madeleine K. Albright and William S. Cohen, Preventing Genocide: A Blueprint for U.S. Policymakers (Washington: Genocide Prevention Task Force, 2008), http://www.usip.org/genocide_taskforce/report.html.

3. Gwynne Dyer, Climate Wars: The Fight for Survival as the World Overheats (Oxford: Oneworld Publications, 2010), 10.

4. Ibid.

5. Sarah Sewall, Dwight Raymond, and Sally Chin, Mass Atrocity Response Operations; A Military Planning Handbook (Cambridge, MA: Harvard Kennedy School / Carr Centre for Human Rights Policy, 2010), 5. Subsequent references appear parenthetically in the text.

6. Marko Attila Hoare, "A Case Study in Underachievement: The International Courts and Genocide in Bosnia-Herzegovina," Abstract, Genocide Studies and Prevention 6, no. 1 (2011): 81.

7. Ibid. 